\title{
Income inequality in central Spain, 1690-1800
}

\author{
Carlos Santiago-Caballero \\ Department of Economic History and Institutions, Universidad Carlos III de Madrid, C/Madrid 126, 28903 Getafe, Spain
}

\section{A R T I C L E I N F O}

\section{Article history:}

Received 12 March 2010

Available online 16 October 2010

\section{JEL classification:}

D63

N33

N53

01

018

Q15

\section{Keywords:}

Agrarian history

Inequality

Pressure groups

Institutions

\begin{abstract}
A B S T R A C T
This paper studies the evolution of income inequality in central Spain during the late seventeenth and eighteenth centuries, taking as case study the province of Guadalajara. The first part of the paper presents the sources and the dataset that was created to estimate income inequality using grain tithes. The second section shows that through the period grain represented the lion share of total income and therefore that it can be used as a reliable proxy. The following part of the paper introduces an analysis of income inequality in the province during the period 16901800 and concludes that inequality decreased during the last third of the eighteenth century. Finally the paper addresses this unexpected result and concludes that it was consequence of the success of the land reform carried out by the central government in the late 1760s. The reform was a success in Guadalajara, thanks to the characteristics of its population and the lack of bargaining power of pressure groups.
\end{abstract}

The following paper studies the evolution of income inequality in the province of Guadalajara during the period 16901800 . There are several reasons that support the choice of Guadalajara as a case study. Like most of the regions in late 17th century Europe, Guadalajara was a typical pre modern province characterised by an almost entire reliance on agriculture and small scale subsistence production. Its study will allow us to obtain conclusions that could easily be extrapolated to other areas of the continent with similar socioeconomic characteristics. Guadalajara is also an interesting case study given its close geographical proximity to Madrid. The capital of Spain depended heavily on the imports of grains from the surrounding regions, and Guadalajara with a surplus of grain was one of the suppliers to the city. ${ }^{1}$ The study of Guadalajara is therefore interesting from the point of view of economic geography, to empirically examine what were the effects on inequality of a growth pole like Madrid on its surrounding areas.

A significant part of the research is based on the creation of an extensive dataset with more than 112,000 observations. Therefore the first part of the paper will present the primary sources that are used in the study, examining their origins, reliability, and the way they are used in our research. The second part of the paper will establish that grain production represented the lion share of total incomes in our sample, and therefore that it is a reliable proxy to measure income inequality. The next section will study the evolution of inequality during the period 16901800 , to conclude that inequality between grain producers in Guadalajara diminished during the last third of the eighteenth century. This finding contradicts the traditional literature on Spanish economic history that considers the eighteenth century a period of increasing inequality. The following part of the paper

\footnotetext{
it Financial support from the Spanish Ministry of Science and Innovation project "Explicando el desarrollo de las regiones europeas, 1850-2008” ECO200913331-C02-01 and from the HI-POD Project, Seventh Research Framework Programme Contract no. 225342" is acknowledged. E-mail address:carlos.santiago@uc3m.es.

URL: http://www.uc3m.es/portal/page/portal/dpto_historia_economica_inst/profesorado/carlos_santiago_caballero.

1 Our estimations show that in the early 1750s Guadalajara produced 750,435 fanegas of wheat and consumed 635,130, obtaining a surplus that could maintain almost 20,000 inhabitants.
} 
will examine the dynamics of the decrease in inequality, showing that the reduction in the proportion of small peasants was the key factor. The next section will look more in depth into the changes in inequality using a Theil index taking into account three dimensions, the size of the municipality, the access to a major road and the amount of rural workers. Finally the paper will argue that the most plausible explanation to this fall in inequality was an agrarian reform carried out by the Bourbon governments that ordered the allocation of common lands owned by local councils between small producers. The intention of the government was guaranteeing the supply of food in large urban areas like Madrid, encouraging the creation of a middle class of peasants. This new social class would be wealthy enough to promote demographic growth and to constitute the economic foundations of the kingdom. In that sense the reform worked in Guadalajara, where the number of producers increased, the amount of very small producers was reduced, and population growth was sustained while it stagnated in the rest of the interior. We will conclude that the most important reason for the success of the reform in the province was the equality that existed between grain producers of Guadalajara. In line with Engerman and Sokoloff (2002), the lack of bargaining power from local oligarchies facilitated the development of the reform, and made possible the success of an economically efficient institutional framework.

\section{Primary sources}

From Old English teotha (tenth), the tithe represented a yearly tax that had to be paid by every producer to the ecclesiastical authorities. The first citations to the tithe can be found in the Old Testament, where according to the Genesis Abram paid the tithe to Melchizedek, the King of Salem (Jerusalem) who also occupied the charge or priest of El Elyon ("the Most High God") (Genesis 14:18). It was a common feature in the economic framework of the middle ages and of modern European countries. In Spain the tithe survived until the Desamortizacion of Mendizabal, a process of confiscation of ecclesiastical properties led by the liberal Spanish government in 1837. During the eighteenth century the tithe paid by producers in Guadalajara represented the usual $10 \%$ of the harvest. The description of the tithes and the way the tax was defined was perfectly explained in 18th century manuscripts.

“... in this village of Alboreca there are several taxes, tithe rights and primicia that in the case of wheat, barley and oats for every ten fanegas one is paid. In the case of wool one out of ten [units], one lamb out of every ten and also one cheese out of every ten, and that in the primicia one half fanega is paid for every eleven, for all these species and also for rye and peas if they are cultivated. If that amount is not reached everything that exceeds ten will be collected until the previously mentioned eleven. And although the harvest exceeded those eleven nothing else will be paid. And if the production does not reach ten half fanegas then nothing will be paid at all from this right of primicias, understanding that this right is not performed in the case of oats, and that it is a right that is property of the priest of the parish of the mentioned village of Alboreca and as such he receives it. ${ }^{2}$

The excellent quality of the tithes encouraged its use to analyse the evolution of agrarian production in Spain. The analysis of tithe series facilitated the publication of a significant number of regional studies in medieval and early modern times. ${ }^{3}$ However the sources used in these studies were usually obtained from the archives of the bishoprics, meaning that they are normally aggregated yearly records for the whole dioceses or shires. The richness of the tazmia books used in this paper allows the researcher a very detailed and unique analysis of the economic reality of grain producers in Spain. Although tazmia books have been used in other regions to estimate the evolution of total production over time, this is the first time that they are being used to calculate the changes in income inequality and therefore open a very promising line of research.

The tazmia books contain the information about the tithes paid in every parish. They are a very rich source of information for economic historians, and include detailed records about the amount of grain that was taxed by the church to every peasant in every town and village every year. This level of detail is extremely rare for early modern times, as most of the records in countries like England only kept the total amount of product taxed and not the distribution by producer. Every year after the harvest an official collector examined the amount of grain produced by every peasant and determined the $10 \%$ that had to be paid as tax. The collector was normally a neighbour of the village who therefore had local knowledge of the area he had to control. His salary was based on the amount of grain taxed, a fact that acted as an incentive to minimise the principal agent problems between him and the ecclesiastical authorities (Alvarez Vazquez, 1984 :76). The Sinodal Constitutions of 1606 demanded that the tithe had to be paid from the total amount of grain produced, before extracting any sort of production costs or even the seeds required for the following harvest (Melon Jimenez, 1987:181). The grain was normally examined by the collector in the same field right after the harvest, and it could not be touched or moved by the peasant until the amount to be paid was determined. The grain taxed in every parish was usually kept in a specific building where the costs that included the salary of the collector were subtracted. The grain that remained was then distributed between the local priest, the bishop, and also civil authorities. The major beneficiary was the church, obtaining the shares for the local priest and the bishop, effectively taking the lion share of the amount collected.

When all the tithes had been determined the priest wrote the tazmia book, a document where year after year he registered the names of all the producers and the amount taxed to each one. The original records for the year were given to the official collector, and a copy was sent to the archives of the bishop. Finally the priest included another copy of the tithes paid which were added to the books that he kept himself and that are now the manuscripts that we have used in our research. At the end of all the records in

\footnotetext{
2 Catastro de la Ensenada. Book of Alboreca, pp. 241-242.

${ }^{3}$ For example they have been used to estimate the evolution of grain production in Valencia (Ardit Lucas, 1989; Palop Ramos, 1982), Malaga (Benitez SanchezBlanco, 1982), Basque Country (Bilbao and Fernández de Pinedo, 1982), Galicia (Eiras Roel, 1982), Segovia (Garcia Sanz, 1982), Murcia (Lemeneunier, 1982), Toledo (Lopez-Salazar Perez and Martin Galan, 1981), Andalucia (Ponsot, 1969), Leon (Sebastián Amarilla, 1992) or Mallorca (Vidal, 1978).
} 
the book, the priest included a personal declaration stating that the details included were accurate and that all the producers had been included. The local priest of the village of Angon wrote in 1760:

"I the licenciado Don Juan de Aleman local priest of the village of Angon certify that these tazmias are accurately executed according to what has been declared by the producers, and having published them nothing can be found against them."4

The small average size of the villages in Guadalajara worked in favour of the ecclesiastical authorities and against the possibilities of cheating. The supervision costs were lower than in other areas of Spain like the south where vast agro towns dominated the landscape of the countryside. A good practice that was also imposed by the ecclesiastical authorities required that the priest had to make public the records reading them in a specific mass with the names and the tax paid by every peasant. This mechanism worked also as a defensive measure to prevent cheating, as any member of the community could easily make a complaint about the amounts paid by one of their peers. In the final declaration as showed in the case of Angon, the priest included a note stating if there had been any complain against the records presented by any member of the community. We could not find any final declaration with complaints in any year of our sample, a point that reinforces the reliability of the source.

We included in our research the 22 municipalities whose records still survive in the archive for the period $16901800 .^{5}$ The dataset obtained from the tazmia books includes more than 112,000 observations, extracted from the taxes paid by more than 14,000 producers during the seventeenth and eighteenth centuries. To create the dataset we extracted the tithes paid by all the producers in each one of the municipalities in the sample. The paper begins in 1690 as consequence of the lack of data available for previous years. The last year of our sample was chosen for historical reasons that affected the reliability of the source. It is generally accepted that cheating paying the tithe generalised with the political and social turmoil created by the Napoleonic invasion in the early nineteenth century. ${ }^{6}$ Therefore we chose 1800 as the last year of our sample to be sure that our estimation would be truly represent the evolution of production.

Another key primary source that is used in the paper is the Catastro de la Ensenada, a survey ordered in 1749 that covers more than 15,000 towns and villages in the Crown of Castile. It was created to gather information for the establishment of a new taxation system, and therefore includes information about goods, prices, production, wages, etc. The Catastro is therefore a monumental work that includes extensive information about the Castilian society and economy. Every municipality had to answer to 40 questions giving information about its name, limits, houses, wealth, production, livestock, trade, manufactures as well as a long list of socioeconomic variables. The following map presents the provinces where the survey took place.

The process to answer the questions was perfectly outlined in the governmental order published the 10th of October 1749 . First the major of the village received a letter from the provincial authorities noting the date when the royal order would arrive as well as to make public the information that was attached to it. The second step was the election of a committee in the village that would be responsible to answer the 40 questions. They were chosen by the local council and included two or more experts on the criteria demanded by the order, like the different lands, products, population, etc. The third stage included the arrival of the external authority that had to carry out the questionnaire, with the help of a lawyer, a scrivener, and the experts that were necessary in every case. Then the local authorities with the committee chosen were called to an audience. The last step was the proper answer that the committee had to give to the questions that were annotated by the scrivener. All the members declaring took an oath with the local priest as witness.

The methodology although systematic was long and not always satisfactory. Nevertheless even taking these problems into account, the Catastro is without a doubt the most important descriptive work of Castile of modern times. The survey started by asking the name of the village or town, its political status and its size, municipality and neighbouring settlements. From the 40 questions included in the survey, we can obtain information about economic and social variables for every village in Castile. For instance, question number 14 asked about the amount of food produced both in quantity and value. The exact content of the question was:

"What is the normal value that every year the fruits have produced by the lands of the municipality, and what was their quality."

The answers to the questions were literal, for example, the authorities from the village of Benquerencia de la Serena answered the previous question by stating:

"every fanega of wheat that is harvested in the village considering some years with others is sold in sixteen reales, the one of rye in eleven and the one of barley in eight ..."

The prices and all of the quantitative information included in the Catastro was not just specific for the year when the answers were given, but an average of several years that were normally the five previous to the interview. If that was not the case and the

\footnotetext{
4 Tazmia Book of Alboreca, 1760.

5 The series corresponds to the following municipalities and parishes: Alboreca/San Andres, Alcuneza/San Pedro, Alpedroches/Asuncion de Nuestra Señora, Angon/ Santa Catalina, Anquela del Pedregal/Asuncion de Nuestra Señora, Aragosa/Nuestra Señora de la Paz, Bañuelos/Asuncion de Nuestra Señora, Canales de Molina/San Cristóbal, Cantalojas/San Julian, Castejon de Henares/San Miguel, Ciruelos del Pinar/Santa Magdalena, La Fuensaviñan/Asuncion de Nuestra Señora, Galve de Sorbe/ Asuncion de Nuestra Señora, Herreria/Asuncion de Nuestra Señora, Hijes/Natividad, Ledanca/Asuncion de Nuestra Señora, Miedes de Atienza/Natividad, Mohares/San Cristóbal, Riba de Saelices/Santa Maria Magdalena, Rillo de Gallo/Santo Domingo de Guzman, Santiuste/Transfiguración, Sienes/Santa Eulalia, Torrubia/Asuncion de Nuestra Señora, Trillo/Asuncion de Nuestra Señora, Valdelcubo/Santiago, Villares de Jadraque/Natividad and Villaseca de Henares/San Blas.

${ }^{6}$ Garcia Sanz, A."La produccion de cereales y leguminosas en Castilla la Vieja. Los diezmos del Obispado de Segovia de 1570 a $1800 "$ in Ladurie, E.L.R., and Goy, J., Tithe and agrarian history from the fourteenth to the nineteenth centuries: an essay in comparative history (Cambridge, Cambridge University Press, 1982).

7 Catastro de la Ensenada, book of Benquerencia de la Serena.
} 
value given was the one for a single year, then the information could be affected by short term events and therefore would present methodological problems. Another important aspect to highlight is that the Catastro was carried out over several years, and that if the values given in the answers were the ones of a specific year, then the cross section comparisons could be misleading. Therefore the nature of the answer allows us to avoid these problems and therefore improves the reliability of the source.

The dataset that we created from the Catastro includes variables like the size of the municipality, the number of peasants, shepherds, workers, aristocrats, wages, taxes paid, production of grain and wool prices, etc. The Catastro is used in this paper to estimate the percentage that grain production represented in total income and to study the socioeconomic characteristics of the locations included in our sample.

The paper also includes original baptismal and burial series created for the province of Guadalajara that were extracted from the historical archive of Siguenza Guadalajara. ${ }^{8}$ The yearly baptismal and burial series were combined to estimate the evolution of total population in Guadalajara, a variable that is used in the paper to estimate the evolution of labour force.

\section{Using grain as a proxy of income}

Grain production represented the bulk of the agrarian economy of Guadalajara, and we therefore believe that it is a good proxy of income for the province. However, in order to calculate more accurately how representative grain production was, we used the information provided in the Catastro de la Ensenada to estimate the percentage that grain production represented of total income. The calculation was carried out for the sample of municipalities that are presented in this paper. To estimate agrarian production we used the main tithe records, grains and also wool and lambs were included in the answers to question 16 of the Catastro. We also included all the minor tithes that were normally paid to the local priest and that contain a wide variety of products from vegetables to chickens, pigs, and honey. To be sure that the estimation included the production that was not taxed with the tithe, we used the answers to questions 10,11 and 12 in the Catastro. Question 11 asked about the different products that were produced in the village. We used that information to check what was produced and what did not appear in the information about tithes. However, the question does not reveal the amount of each item that was actually being produced. We can nevertheless estimate this amount indirectly through the information provided in questions 10 and 12 of the Catastro. Answer to question 10 explained the different types of land including quality, the size of each plot and more importantly the products that were being cultivated on each one. The answer to question 12 showed the productivity of each sort of land depending on what product was cultivated on them. Therefore, combining the land that was being dedicated to each product and the productivity, we were able to estimate the production that was not included in the tithes. Finally, the information to answer question 14 presented the average prices of the products cultivated in the municipality that were used to transform the production from kind to cash.

To complete the estimation of income we also included information about wages. In every village there was normally a priest, baker, etc. and their income should also be included in the calculations. The Catastro presents information about the wages and incomes of that part of the population that was added to agrarian production. To complete the estimation we also included the information about part time jobs carried out by peasants while they were not directly engaged in agriculture. Some of the salaries were paid in kind (normally wheat) and in those cases, as in agrarian production, salaries were transformed into cash to be aggregated.

Table 1 shows an example of how total incomes were calculated for each municipality. First of all we calculated the incomes generated from the primary sector by estimating the production in kind and then in cash using the local prices paid by each item. Secondly we estimated the incomes derived from the secondary and tertiary sectors by using the yearly wages estimated for every worker in the municipality. We finally estimated the percentage of the total income that the production of grain represented.

We established that in the early 1750s grain production in our sample represented around 70\% of total income. However we believe that this number changed over time during the eighteenth century. Our estimations show that in the early 1750 s, $72 \%$ of the income in our sample came from grain production, $14 \%$ from wages and $14 \%$ from other agrarian production. Using this information as starting point, we created several indexes to measure the evolution of output and labour during the eighteenth century and then used them to re estimate the decadal distribution of income. To estimate the evolution of income derived from grain production we used yearly grain tithe series for wheat, barley, rye and oats in Guadalajara that were transformed into cash using grain price series. In the case of wages we estimated the changes in labour force by calculating the evolution of population. From yearly baptismal and burial records from Guadalajara we created a population index as proxy of labour force. We then combined the population index with an index of real wages for New Castile to obtain the evolution of total income derived from salaries. ${ }^{9}$ We do not count on yearly series of other primary products and therefore cannot control how it changed during the century. However we decided to proxy it using grain production series assuming that the increases and decreases of production were mainly based on changes in climatic conditions. Therefore we assume that the years of bad grain harvests were also years of bad harvests in fruits, vegetables, etc. The products included in this calculation were mainly cultivated in the rich and fertile lands

\footnotetext{
${ }^{8}$ Baptismal series include the following municipalities and parishes: Albares/San Esteban, Anchuela del Pedregal/San Andres, Anquela del Ducado/San Martin, Arroyo/Inmaculada, Bañuelos/Asunción de Nuestra Señora, La Bodera/Santiago, Cantalojas/San Julian, Cañizares, Castilmimbre/Asunción de Nuestra Señora, Ciruelos del Pinar/Santa Magdalena, La Cobeta/Asunción de Nuestra Señora, Concha/San Juan Bautista, Congostrina/Asunción de Nuestra Señora, Galve de Sorbe/ Asunción de Nuestra Señora, Garbajosa/San Miguel, Hijes/Natividad, Milmarcos/San Juan Bautista, Olmeda de Jadraque/San Mateo, Peralejos de las Truchas/San Mateo, Renales/San Sebastián, Riba de Saelices/Santa Maria Magdalena, Setiles/Asunción de Nuestra Señora, Sienes/Santa Eulalia, Somolinos/Inmaculada and Torrubia/Asunción de Nuestra Señora. Burial series were extracted from the municipalities of Cantalojas, Hijes, Galve de Sorbe, Bañuelos, Somolinos, Milmarcos, Valdelcubo, Torrubia, Adobes and Azañon.

${ }^{9}$ The real wages index was extracted from (Llopis Agelan and García Montero, 2009).
} 
Table 1

Calculation of total income in the village of Bañuelos, early 1750 s (in reales).

\begin{tabular}{|c|c|c|c|c|c|}
\hline & Amount of land & Output per unit of land & Total output & Price per unit produced (reales) & Value \\
\hline Vegetables & 10 & 25.0 & 250 & 3.0 & 75 \\
\hline Hemp & 10 & 283.0 & 2830 & 0.2 & 51 \\
\hline Hemp Seed & 10 & 1.5 & 15 & 2.0 & 30 \\
\hline Fruit & 3 & 10.0 & 30 & 5.0 & 15 \\
\hline Wheat & & & 4780 & 15.0 & 71,700 \\
\hline Barley & & & 2260 & 7.5 & 16,950 \\
\hline Oats & & & 120 & 7.5 & 900 \\
\hline Lambs & & & 460 & 8.0 & 3680 \\
\hline Wool & & & 1970 & 1.0 & 1970 \\
\hline \multicolumn{5}{|c|}{ Total Primary Sector } & 96,000 \\
\hline \multicolumn{5}{|l|}{ Wages } & 20,665 \\
\hline \multicolumn{5}{|c|}{ Total Income } & 116,665 \\
\hline \multicolumn{5}{|c|}{ \% Grains (Wheat, Barley, Rye and Oats) } & $76.8 \%$ \\
\hline
\end{tabular}

Source: Catastro de la Ensenada. Book of Bañuelos.

next to the riverbanks that were the first ones to be fully exploited. We therefore do not expect significant changes in the area cultivated, and consequently changes in total output derived from the use of more land are improbable. The decision seems to be correct also in the case of livestock that depended on the availability of grain, especially rye and oats that were essential to feed the animals. We transformed the production index into cash by using a price index of primary products where we did not include the prices of the four grains (Fig. 1).

The results shown in Fig. 2 indicate that in the early eighteenth century grain production represented 70\% of total income, a figure that remained stable during the first half of the century with the exception of 1720 when the figure decreased to $64 \%$. The situation changed during the second half of the century when the percentage rose gradually to reach $84 \%$ in 1800 . This process was mainly consequence of the inflation in grain prices that increased more rapidly than prices from other products while real wages in New Castile declined rapidly. By 1800 real wages in New Castile had been reduced to half the levels reached in 1750 . Therefore we believe that the use of grain production as an estimator of incomes was good during the whole century, improving over time and reaching its maximum reliability during the last decades.

\section{Gini coefficient}

The Gini Coefficient measures the dispersion of the observations in a sample and has been widely used to measure inequality. The coefficient takes values between 0 and 1 attributing a value of 0 to perfect equality and a value of 1 to perfect inequality. In other words and in the case that we are studying, the Gini Coefficient would be 0 if all the peasants produce exactly the same amount of grain and 1 if one single peasant owns all the production. In mathematical terms the Gini Coefficient can be defined as:

$$
G_{1}=1-\sum_{k=1}^{n}\left(X_{k}-X_{k} 1\right)\left(Y_{k}+Y_{k} 1\right)
$$

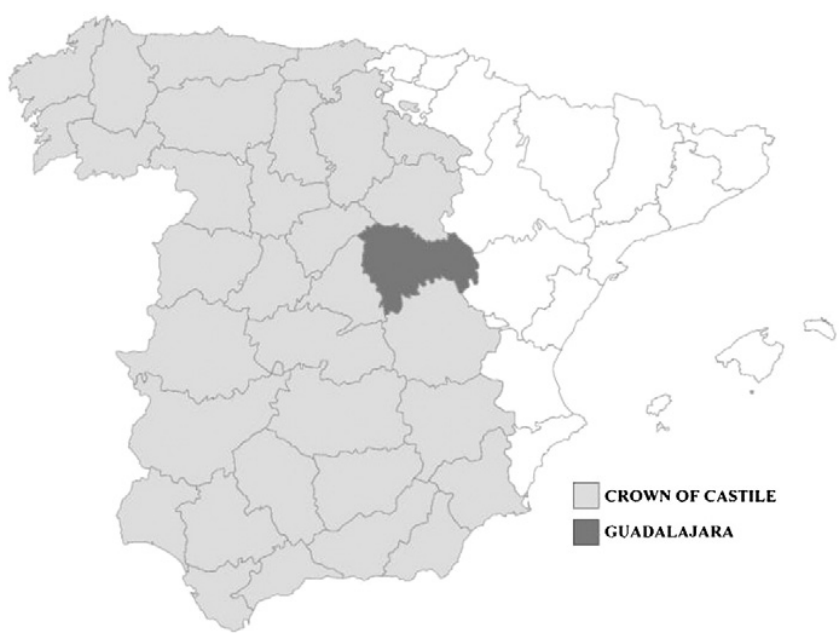

Fig. 1. Guadalajara within the Crown of Castile. 


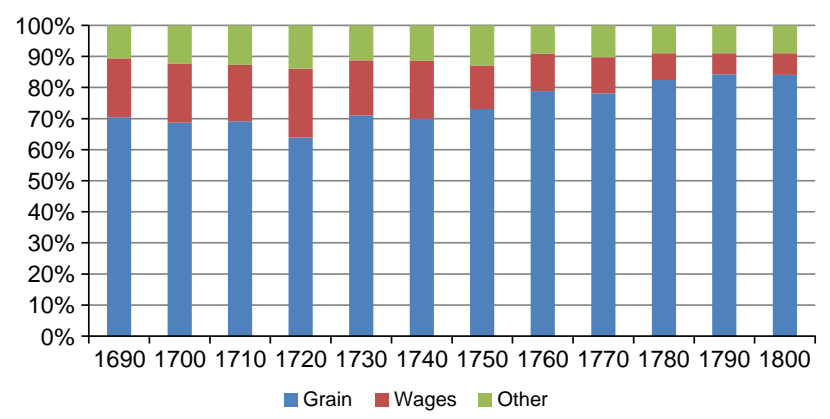

Fig. 2. Share of total income in Guadalajara, 1690-1800.

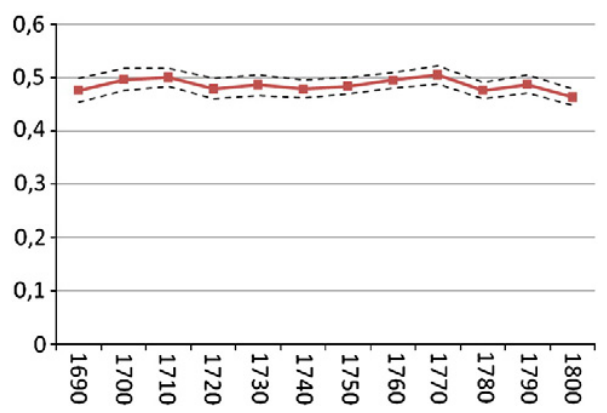

Fig. 3. Decadal Gini coefficient in Guadalajara, 1700-1800. The dashesd line represents the confidence intervals at a 95 per cent level. Sources: Same as Footnote 5.

Where $G$ is the Gini coefficient, $X$ is the cumulated proportion of the population variable and $Y$ is the cumulated proportion of the production of cereals. Using the information provided by the Tazmias books from around 15,000 producers and following the methodology presented above, we generated decadal calculations of the Gini coefficient for cereal production in Guadalajara. We used bootstrap methods in order to estimate standard errors and to construct confidence intervals that would reveal if the changes detected are statistically significant. ${ }^{10}$

The results showed in Fig. 3 reveal four long term trends during the period. The first one shows an increase in inequality levels from 1690 until 1710. The second period shows convergence and inequality reduction from 1710 until 1740 . The third one shows an increase of inequality starting around 1750 and ending around 1770 . The last period shows again convergence between producers that took place from 1770 until the end of the century. The long term trend shows a period of convergence between small and big producers, when inequality in cereal production was reduced. However the confidence intervals determine that the only change that was statistically significant at the $95 \%$ level was the decrease between 1770 and 1800 . Other inequality proxies present a very similar behaviour. Fig. 4 shows that the results for the Theil index follow the same trends previously shown in the Gini coefficient. The share of output owned by the top $1 \%$ and bottom $10 \%$ distributions showed in Figs. 5 and 6 also indicate the same evolution reinforcing the conclusions obtained from the Gini coefficient.

The decrease that took place between 1770 and 1800 was the only one that was statistically significant at the $95 \%$ level. But what was the economic effect of the reduction in the Gini coefficient from 0.51 to 0.47 that took place during the last third of the eighteenth century? Was it consequence of small producers catching up? We can provide some answer to these questions. In our sample, doubling the production of the bottom $12 \%$ would reduce the Gini coefficient by 0.1 points. To reduce it by 0.4 points, that is the reduction that took place during the late eighteenth century we would have to double the production of the bottom $33 \%$ of the distribution. These are therefore not small changes, and the economic effects especially in the situation of the bottom part of the distribution could be important.

To better understand what was driving inequality changes we divided all producers at each turning point into 10 equal sized groups depending on their production levels using deciles. The first group therefore includes the number of peasants whose production levels were between 0 and $9.9 \%$ of the output of the biggest producer, the second one 1019.9 , etc. Fig. 7

\footnotetext{
${ }^{10}$ The method uses bootstrapping following Steckel and Moehling (2001).
} 


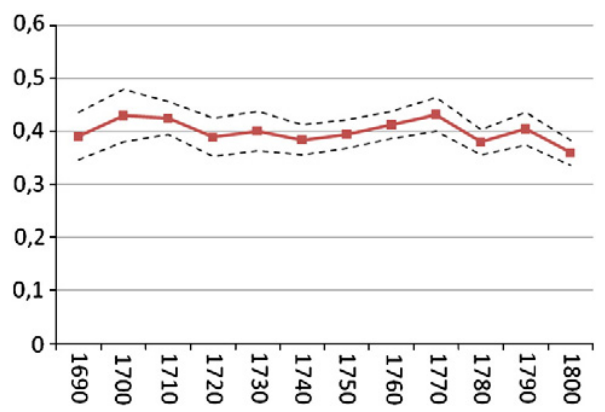

Fig. 4. Decadal Theil index in Guadalajara, 1700-1800. The dashesd line represents the confidence intervals at a 95 per cent level. Sources: Same as Footnote 5.

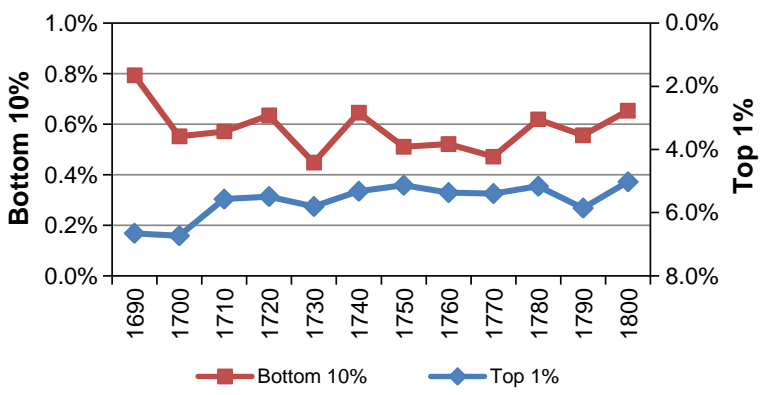

Fig. 5. Output share of the top $1 \%$ and bottom $10 \%, 1690-1800$. Sources: Same as Footnote 5.

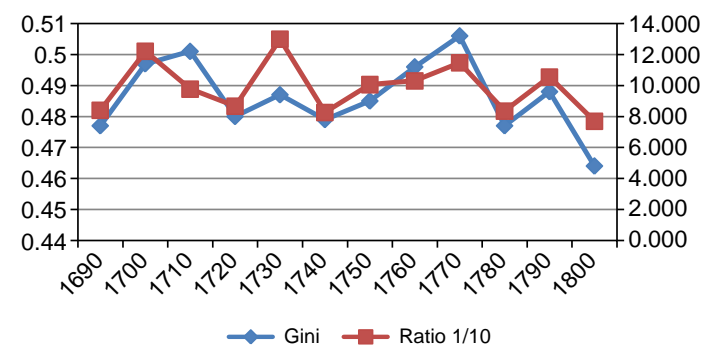

Fig. 6. Gini coefficient and ratio share top 1\%/bottom 10\%, 1690-1800. Sources: Same as Footnote 5.

shows that between 1770 and 1800 the biggest change took place in the first decile, which decreased by $8 \%$. Most of these small producers jumped into the second decile, while the third, fourth, fifth and sixth also show increases although less significant.

Fig. 8 shows a more detailed analysis of the movements which took place within the first decile. The results reveal that it was within the first two percentiles where the largest decrease took place, followed by the 35 percentiles. We can therefore confirm that the decrease in income inequality was mainly a consequence of very small producers improving their positions.

\section{The internal dynamics of inequality changes (Theil)}

Although the Gini coefficient is a good way of measuring the changes in total inequality, it also has limitations. A different way of measuring inequality levels is the use of generalized entropy measures like the Theil Index, a measurement that has also been widely used in the literature of income inequality (Steckel and Moehling, 2001; Mora Sitja, 2006). Although the properties of the Theil Index are very similar to those of the Gini coefficient, it allows deeper analysis of the data and it can be easily decomposed. In other words, if we divide our sample of producers in different groups by village, by production, etc. the Theil index will show us if 


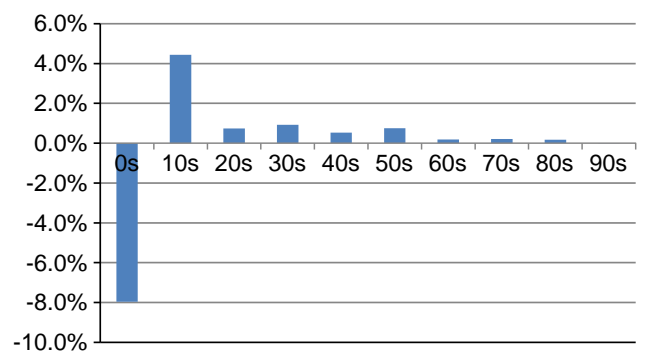

Fig. 7. Changes in the distribution of the production, 1770/1800. Sources: Same as Footnote 5.

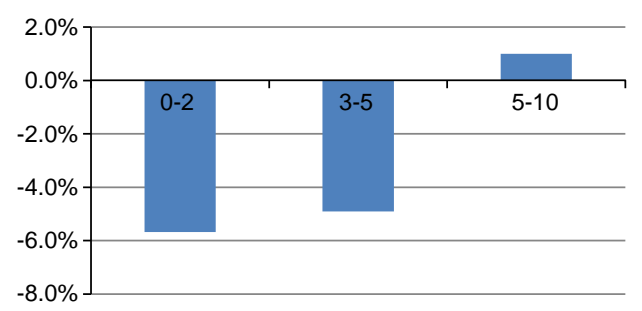

Fig. 8. Changes in the distribution within the first decile, 1770/1800. Sources: Same as Footnote 5.

the changes in inequality identified are a consequence of changes of inequality within those groups or between them. Its calculation is defined by the formula:

$$
T=\frac{1}{n} \sum_{i=1}^{n} \frac{w_{i}}{\mu} \ln \left(\frac{w_{i}}{\mu}\right)
$$

In our case, $n$ would be the number of producers, $w_{i}$ the production of the individual $i$ and $\mu$ the arithmetical average of the sample. If we divide the observations of a sample in different groups, the Theil index can tell us what the changes in inequality within and between each group are. In our case we decided to divide the producers in the sample by villages grouping them by size. Therefore, three groups were created with small, medium and big villages. There are good reasons to support this division, as the size of the village also defined its economic and social structure. Small villages were mainly occupied by a homogenous group of small peasants that were owners, while big villages included also manufactures producers and workers that did not own land. We can therefore expect differences in inequality between the three groups that can be explored by the Theil index. Following the methodology presented above, for every group $g, \mu$ is the average production, ng the number of producers and $\mathrm{Tg}$ is the Theil index for that specific group. The new formula for the Theil index is:

$$
T=\sum_{g=1}^{G} \frac{n_{g} \mu_{g}}{n \mu} T_{g}+\sum_{g=1}^{G} \frac{n_{g} \mu_{g}}{n \mu} \ln \left(\frac{\mu_{g}}{\mu}\right)
$$

Being

$$
T_{g}=\frac{1}{n_{g}} \sum_{i=1}^{n g} \frac{w_{i}}{\mu_{g}} \ln \left(\frac{w_{i}}{\mu_{g}}\right)
$$

The first term in (3) corresponds to the weighted addition of the Theil indexes of every group and therefore presents inequality within each group; in other words, it measures inequality within small, medium and big villages. The second term shows inequality between the three groups.

Finally, the Theil index can be also decomposed into three elements; changes in the proportion of the population of the groups (4), changes in the relative average of the groups (5) and finally changes in the dispersion of the production within groups (6)

$$
\Delta T_{n}^{t, s}=\Delta T_{\text {within, } n}^{t, s}+\Delta T_{\text {between }, n}^{t, s}=\sum_{g=1}^{G}\left[\left(\frac{n_{g}^{t}}{n^{t}}-\frac{n_{g}^{t}}{n^{s}}\right) \frac{\mu_{g}^{t}}{\mu^{t}} T_{g}^{t}\right]+\sum_{g=1}^{G}\left[\left(\frac{n_{g}^{t}}{n^{t}}-\frac{n_{g}^{s}}{n^{s}}\right) \frac{\mu_{g}^{t}}{\mu^{t}} \ln \left(\frac{\mu_{g}^{t}}{\mu^{t}}\right)\right]
$$


Table 2

Inequality changes decomposed by size of village.

\begin{tabular}{|c|c|}
\hline & $1770-1800$ \\
\hline Inequality within groups & $107 \%$ \\
\hline Small & $5 \%$ \\
\hline Medium & $74 \%$ \\
\hline Big & $38 \%$ \\
\hline Inequality between groups & $7 \%$ \\
\hline Total inequality & $100 \%$ \\
\hline
\end{tabular}

Sources: Same as Footnote 5.

$$
\begin{aligned}
& \Delta T_{\mu}^{t, s}=\Delta T_{\text {within } \mu}^{t, s}+\Delta T_{\text {between }, \mu}^{t, s}=\sum_{g=1}^{G}\left[\left(\frac{\mu_{g}^{t}}{\mu^{t}}-\frac{\mu_{g}^{s}}{\mu^{s}}\right) \frac{n_{g}^{s}}{n^{s}} T_{g}^{t}\right]+\sum_{g=1}^{G}\left[\frac{\mu_{g}^{t}}{\mu^{t}} \ln \left(\frac{\mu_{g}^{t}}{\mu^{t}}\right)-\frac{\mu_{g}^{s}}{\mu^{s}} \ln \left(\frac{\mu_{g}^{s}}{\mu^{s}}\right)\right] \frac{n_{g}^{s}}{n^{s}} \\
& \Delta T_{T}^{t, s}=\sum_{g=1}^{G} \frac{n_{g}^{s} \mu_{g}^{s}}{n^{s} \mu^{s}}\left(T_{g s}^{t}-T_{g}^{s}\right)
\end{aligned}
$$

Table 2 shows that during the period 17701800 the reduction of inequality was mainly driven by group convergence, especially in medium and big villages. On the other hand, there was a small increase in the inequality within small villages. The reason was that in small villages inequality levels were already low in 1770, while high inequality levels in medium and big villages were reduced during the following three decades. Overall the eighteenth century was a period of convergence in the three groups of villages, although bigger villages reduced inequality levels at a more intense rate(where the Theil Index fell by 5 points). On the other hand, the decline of inequality in small and medium villages was more moderate with a reduction of 1 point. Most of the reduction in big villages took place during the late eighteenth century when the Theil index in the group fell by 10 points. The study of the Gini coefficient shows very similar results with a fall of 1 point in medium villages between 1710 and 1800,2 points in small ones and again a considerable decrease in big villages where the Gini coefficient fell by 3 points during the same period.

The existence of rural workers also played a role in the different evolution of inequality changes. We divided our sample depending on the percentage of rural workers that lived in each municipality. The first group included all locations where there were no rural workers, the second group comprised of the municipalities where rural workers existed. Table 3 shows that most of the change took place within groups, and that inequality decreased in both. However the decline was more intense in the municipalities where there were no rural workers, more than doubling the decrease that took place in the locations where there was a presence of workers.

We also studied the effect that roads had in inequality changes, dividing our sample between the municipalities that had a direct access to a major road and those that did not. Table 4 shows that after 1770 inequality fell more in the locations that were not connected to the main national roads that crossed the province. A possible answer to this result relies on the average size of the municipalities, smaller on average in the municipalities connected to a major road than the size of the locations that were not connected.

In summary, inequality between grain producers in Guadalajara fell during the eighteenth century, mainly thanks to the decline that took place from 1770 . The process was characterised by a reduction in the proportion of very small producers that became medium producers and that was especially intense in medium and big villages. The absence of rural workers also facilitated the reduction in inequality. Finally inequality decreased more in those locations that were not connected to a main road. But how was this possible? The eighteenth century is considered by the literature a period of increasing inequality when the differences between rich and poor increased. What was different in Guadalajara and what was the trigger behind the changes? The answer can be found in the land reforms that were carried out by the central governments during the late 1760 s.

\section{The success of institutional change}

The last third of the eighteenth century in Spain was a period dominated by the introduction of agrarian reforms. One of the most important goals of the government was the creation of a pool of medium producers that would become the fiscal core of the country. In order to increase the protection of land tenants, new legislation was introduced by the government in 1763 . The main purpose of the reform was to imitate the English model increasing the security of the tenant in the long run. In 1785 the government regulated the requirements necessary for a landowner to terminate the contract with his tenant, with the idea of avoiding random unjustified expulsions. $^{11}$

\footnotetext{
11 González Enciso (1992:237).
} 
Table 3

Inequality changes decomposed by number of rural workers.

\begin{tabular}{|c|c|}
\hline & $1770-1800$ \\
\hline Inequality within groups & $93 \%$ \\
\hline Rural workers & $28 \%$ \\
\hline No rural workers & $65 \%$ \\
\hline Inequality between groups & $7 \%$ \\
\hline Total inequality & $100 \%$ \\
\hline
\end{tabular}

Sources: Same as Footnote 5.

Table 4

Inequality changes decomposed by proximity to road.

\begin{tabular}{|c|c|}
\hline & $1770-1800$ \\
\hline Inequality within groups & $86 \%$ \\
\hline Road & $16 \%$ \\
\hline No Road & $70 \%$ \\
\hline Inequality between groups & $14 \%$ \\
\hline Total inequality & $100 \%$ \\
\hline
\end{tabular}

Sources: Same as Footnote 5.

Price instability and the capacity to guarantee the supply of food were also issues in the agenda of the authorities. The price of grain in Spain increased substantially during the 1750 s, a situation that the government attributed to the lack of internal trade. To incentivise the commercialisation of grain, on July 11, 1765 the government liberalised grain trade freeing prices which had been controlled until that point. The new law also allowed the reselling of grain which had been forbidden until then. The importance of internal trade was highlighted by contemporary politicians like Jovellanos, who wrote that it would benefit regions with a surplus of grain. According to Jovellanos, with the new revenues those regions could serve as market for national manufactures (Jovellanos, 17441788 ). ${ }^{12}$ The growth of prices encouraged the increase of grain production during the $1750 \mathrm{~s}$, mainly as a consequence of an increase in the number of producers. This situation was probably the cause of an increase in inequality between grain producers in Guadalajara during the period 1740 1770, when we observe that the number and proportion of very small producers increased. This created a problem for many of these very small producers that in years of bad harvests they had to rely on the market to command enough food (Llopis, 2002:142).

In 1766 the rise of the price of bread in Madrid acted as a catalyst for the Esquilache riot that forced Carlos III to flee Madrid. The revolt worked as a warning signal for the government which immediately adopted measures to increase food production and to distribute land more equally. In May 1766 the first orders were issued to begin the redistribution of common lands owned by the local councils in Extremadura. The measure was extended to Andalusia in June 1767 and to the rest of the country on May 20 th $1770 .{ }^{13}$ The reform gave preference to those with no land (jornaleros) but in reality rural workers had little chances of obtaining a piece of land. The law was clear stating that the new owner had to prove having enough funds to pay for the tools, seeds, and other inputs required to use it, imposing de facto a barrier impossible to break for many rural workers. ${ }^{14}$ On the other hand, small owners and tenants were among the most benefited by the reform. In exchange for the land, the peasant had to pay a rent based on the harvest and had to exploit the plot directly. The fact that such tight conditions were imposed explains why the reform failed in those areas where the proportion of poor rural workers was high. In certain parts of Spain the power of local oligarchies tried to sabotage the reform and in many cases succeeded. This was once more particularly important in areas where the amount of rural workers was high, and the power of big landowners more prevalent.

In the Castilian province of Segovia the land reform failed because of the lack of physical capital in the hands of rural workers, who did not own the tools which were a prerequisite to have access to the distribution of land (Garcia Sanz, 1984:258). The other factor that limited the success of the reform in Segovia was the ability of the privileged classes to manipulate the distribution of common land. Pressure groups of big landowners in Segovia controlled the sexmos, the institution responsible for redistributing common lands that imposed restrictions to rural workers and small peasants. In a similar case, Sanchez Salazar argued that in areas of southern Spain the land reform failed as consequence of the same reasons, lack of physical capital from the rural workers and a strong influence of big landowners (Sanchez Salazar, 1984:266). While the legal framework kept rural workers out of the redistribution, the economic elites also found legal ways to weaken the rights of the small peasant. For instance the authorities

\footnotetext{
12 Jovellanos addressed several economic issues in his Informe Sobre la Ley Agraria (Report on the Agrarian Law) where he also pointed out to the importance of increasing competition in the grain market.

13 González Enciso (1992:237).

14 The rules that regulated access to common lands were published in the Real Providencia of May 23 and 24, 1770. Artola (1982:143).
} 
Table 5

Population density, rural workers and poor people early 1750 s.

\begin{tabular}{lcrr}
\hline & Density & Workers/1000 \\
\hline North & 34.1 & 5 & 9 \\
South & 18.8 & 186 & 66 \\
Centre-North & 14.8 & 22 & 25 \\
Centre-South & 11.1 & 39 & $\mathbf{9}$ \\
Guadalajara & $\mathbf{9 . 7}$ & 36 & $\mathbf{1 2}$ \\
\hline
\end{tabular}

Source: See Appendix.

could offer them parcels of low quality or at large distances from the village, increasing production costs to levels that forced them to reject the proposal.

However there were cases where the reform was successful. In the province of Malaga the most privileged classes were traditionally engaged not in agriculture, but in commercial and industrial activities (Fernandez Paradas, 2001). This lack of interest in the rural sector reduced the pressure on the local governments that allocated common lands more equally. The consequence according to Fernandez Paradas was that in Malaga "the redistribution [of land] allowed the creation of a numerous group of small tenants".

Success was also the case of Guadalajara, where the extremely low level of rural workers reflected a society where the bargaining power of big landowners was limited. The consequences of the reform in Guadalajara were important and from 1770 until 1800 the number of grain producers increased by $24 \% .{ }^{15}$ However, not only the number of producers grew, as explained above, the levels of inequality between grain producers diminished showing that the reform improved indeed the access of small producers to land.

The results from the analysis of the Theil index in several dimensions reinforce the hypothesis of the land reform as cause. First of all the reduction in inequality levels took place mainly in medium and big villages. According to our calculations before the reform common lands that could be potentially arable represented in small villages $15 \%$ of the total, while in villages of bigger size the proportion increased to $40 \%$. The average coincides with Garcia Sanz's estimations who argued that in 1750 , between 20 and $30 \%$ of the land in Spain was controlled by local councils. ${ }^{16}$ Therefore when the reform took place more land was distributed in medium and larger villages, allowing an intense decrease in inequality between producers in these municipalities. Transports however played a minor role in the reduction of inequality that fell more in the municipalities that were not connected to a major road. Those municipalities that were not connected to a road were on average larger, a situation that could explain why inequality fell more in them. As explained above the percentage of common lands was higher in larger municipalities, and it was in these areas where inequality fell more intensively than in smaller locations. The number of grain producers grew more in the locations that were not connected to the road, showing that indeed the larger size and more availability of common lands was the force behind this situation. Finally as explained before, the existence of rural workers was a significant factor to explain the failure of the reform in other parts of Spain. The major decrease in inequality in our sample took place in those locations that did not have rural workers, indicating again that the agrarian reform was probably the most important cause behind the decrease in inequality.

Therefore, the agrarian reform that failed in other parts of Spain was a success in Guadalajara, where the ideals of the enlightened government of creating a class of medium producers that would encourage demographic growth worked. In this sense the unique characteristics of Guadalajara were fundamental to explain the success of the reform. Guadalajara was a province where land was clearly the most abundant factor. In the early 1750s the population density was 18.6 inhabitants per square kilometre in Spain, 17.2 in Castile, and 9.7 in Guadalajara. ${ }^{17}$ Table 5 shows that the socioeconomic conditions of the inhabitants in Guadalajara were also relatively good with low levels of rural workers and beggars. Therefore before the reform Guadalajara had plenty of land to redistribute and a population with enough resources to fulfil the legal requirements to access it.

The relationship between the socioeconomic characteristics of a society and the success of its institutions has been extensively studied in the literature. Engerman and Sokoloff showed that the egalitarian societies of small grain producers in North America were the key for the development of an efficient institutional framework. On the other hand, the unequal societies of the Caribbean encouraged the creation of more dictatorial regimes that conduced to economic underdevelopment. The existence of social elites that controlled the institutions and modelled them to favour their interests was the key, for the authors, to explain the lack of economic performance in the economies of Central and South America (Engerman and Sokoloff, 2002). Applying the same idea to eighteenth century Spain it is not strange that some authors argued that inequality increased. In the southern half of the country

\footnotetext{
15 Own estimations from tithe books.

16 García Sanz (1980).

17 Own calculations from Fernandez de Pinedo et al. (1980:18)and Lacomba (1999:321).
} 
the power of big landowners was strong and therefore the privatisation of common lands probably reinforced their privileged positions. However, Guadalajara included the best of the two agricultural systems of Spain; the low demographic pressure of the south and the lack of rural workers of the north. Both factors combined explain why the redistribution of common lands in Guadalajara worked better than in the rest of the country. Therefore, following Engerman and Sokoloff's ideas, the lack of powerful pressure groups worked in favour of the agrarian reform.

\section{Conclusions}

The use of information from grain tithes seems to be a reliable source to estimate the evolution of income in Guadalajara. The use of the source shows that the period 17701800 in the province is an age of decreasing inequality, when not only the number of grain producers increased, but also when the differences between them diminished. Taking the period 16901800 as benchmark we observe that against what is suggested by the literature in the case of Spain, the eighteenth century was a period when inequality was reduced in Guadalajara. The study of the Gini Coefficient and the distribution of grain producers, indicate that this convergence was characterised by a significant reduction in the number of very small and small producers. Small villages enjoyed low levels of income inequality during most of the century and therefore there was almost no room to catch up. However, in larger municipalities inequality levels were higher and there was still room to reduce the gap between big and small producers. A detailed analysis of changes in inequality shows that this was the case and that most of the reductions of income inequality were based on catching up of small producers in big villages. In a similar way the municipalities that did not have rural workers benefited from a larger decrease in inequality levels. On the other hand access to the major road network in Spain was not a significant force in the reduction of inequality. The second finding explains how the unexpected decrease in inequality took place. Small peasants were able to increase the size of their exploitations by having access to the privatisation of common lands promoted by the central government. Unlike the period 1740 1770, the availability of the new lands (normally pastures) made possible the absorption of new producers in better conditions. The redistribution of common lands allowed many small peasants to produce above subsistence level and therefore to take advantage of trade and high grain prices. The proportion of common lands was higher in larger villages, a situation that explains why the reduction in inequality was more intense in these sort of municipalities. The reform that failed in other parts of Spain was successful in Guadalajara thanks to the lack of bargaining power of pressure groups, a result of the unique characteristics of the population in Guadalajara. These characteristics combined the best features of the two models of agricultural production in Spain; the high proportion of producers (and lack of rural workers) of the north and the low pressure on natural resources of the south. Therefore, there was land to share and peasants able to fulfil the conditions imposed by the government to access it. In addition, the similar characteristics that existed between grain producers in Guadalajara reinforced the process. In other words and following Engerman and Sokoloff's arguments, the existence of an egalitarian society made possible the adoption of an economically successful reform.

\section{Appendix A. Description of sources}

This section explains in detail the primary and some secondary, as well as the methodology to transform them in the variables used in the paper that have not been described in the text.

The total production of wheat in Guadalajara was extracted from the manuscripts in the Catastro de la Ensenada. Question 15 asked about the taxes that existed in each municipality. We took the information related to the ecclesiastical tithe that represented a $10 \%$ of the total harvest. We gathered the information for all the municipalities of Guadalajara, and by using this data we estimated total production of wheat. We also estimated the population of Guadalajara gathering the answers to question 21 multiplying the number of vecinos (households) by 3.92, following the methodology in Censo de población de la Corona de Castilla "Marqués de la Ensenada. ${ }^{18}$ Then assuming a yearly consumption of 6 fanegas per inhabitant (Simpson, 1989) we estimated the surplus of wheat in the region.

The calculations of inequality were based on the analysis of the production of wheat, barley, rye and oats from around 15,000 producers which is contained in the tithe (tazmias) books. The grains were weighted depending on the prices of each one. These books were consulted in the Historical Diocesan Archive of Sigüenza Guadalajara. The sample of municipalities are described in the text.

The information presented in Table 5 has been extracted from several sources. Population density was calculated from Censo de población de la Corona de Castilla "Marqués de la Ensenada. ${ }^{19}$ The number of rural workers and poor people were extracted directly from the manuscripts in the Catastro de la Ensenada, and more exactly from questions 35 and 36. The population of the municipalities was extracted from question 21. Combining the information from both we calculated the proportions shown in the table.

\footnotetext{
18 INE (1994-1995).

19 INE (1994-1995).
} 
We aggregated data using the current geographical boundaries that are displayed in the following maps.
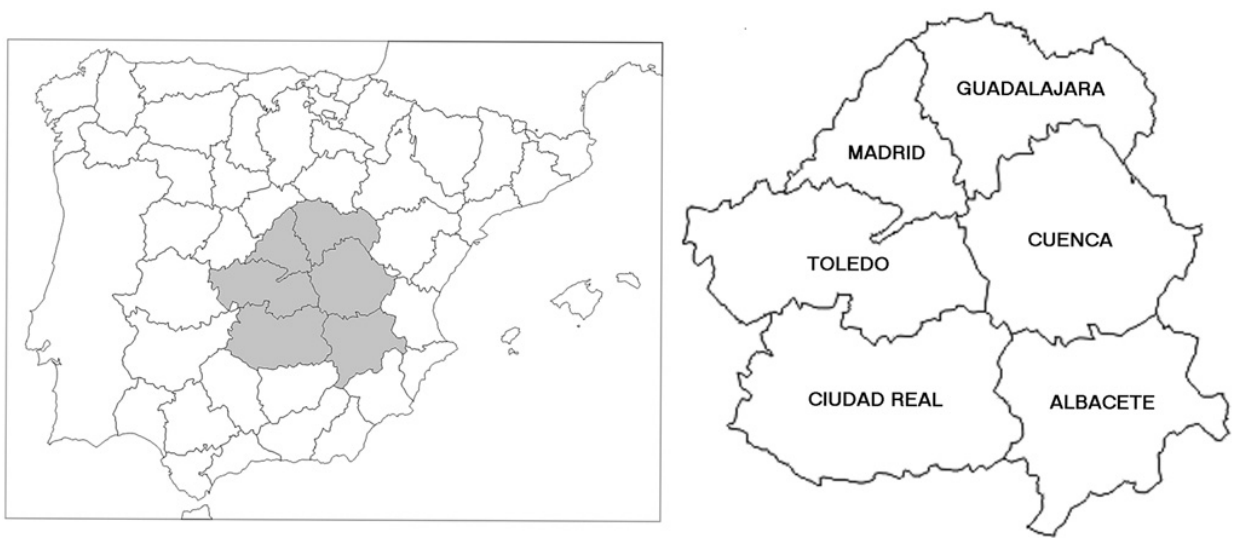

\section{Early modern Spain}

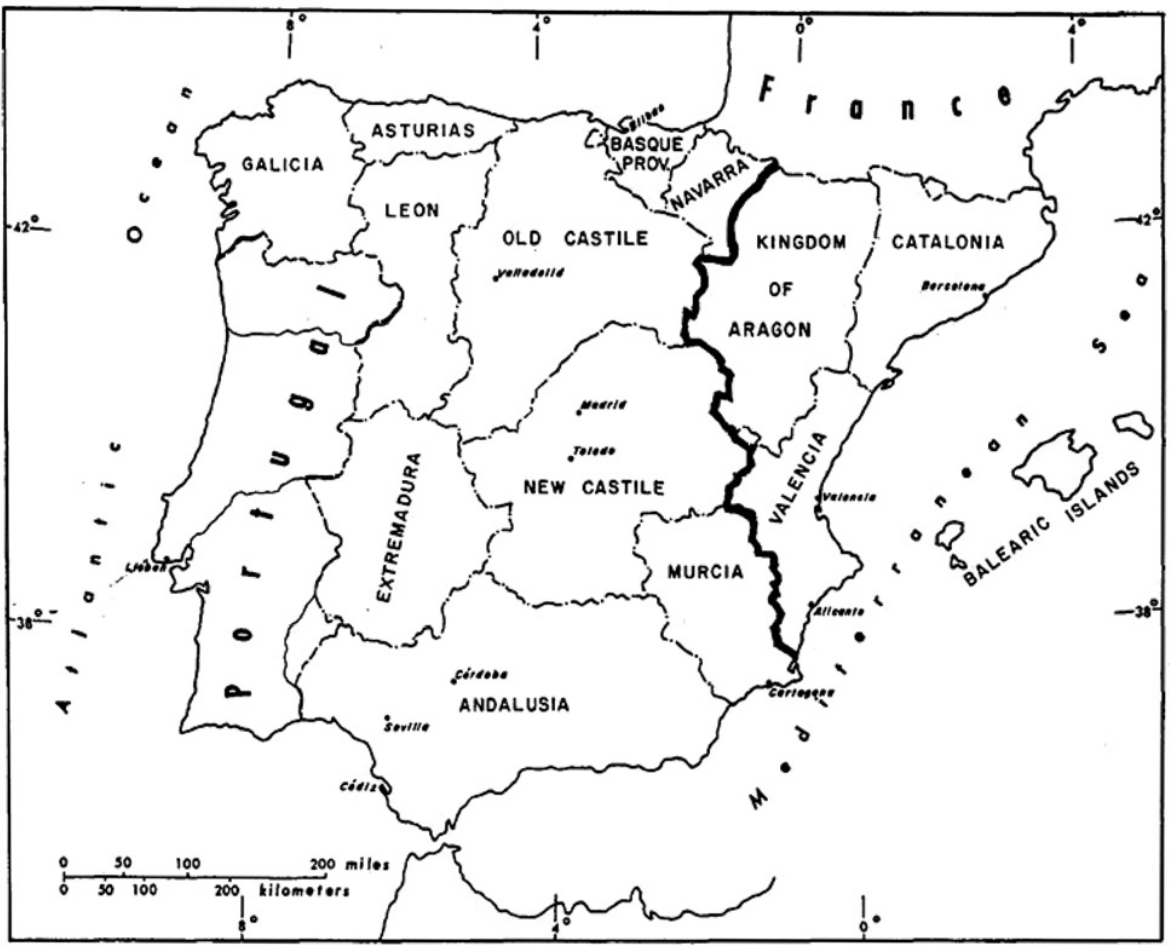

\section{References}

Alvarez Vazquez, J.A., 1984. Los diezmos en Zamora (1500-1840). Universidad de Salamanca, Salamanca.

Ardit Lucas, M., 1989. Recaudación y fraude diezmal en el siglo XVIII valenciano. Estructura agrarias y reformismo ilustrado en la España del siglo XVIII. Ministerio de Agricultura y Pesca, Madrid, pp. 391-410.

Artola, M., 1982. La economía española al final del antiguo régimen. Alianza Editorial, Madrid.

Benitez Sanchez-Blanco, R., 1982. Diezmos andaluces: series malaguenas del diezmo del trigo. In: Goy, J., Le Roy Ladurie, E. (Eds.), Prestations paysannes, dîmes, rente foncière et mouvements de la production agricole à l'époque pré-industrielle. Mouton, París, pp. 295-312.

Bilbao, L.M., Fernández de Pinedo, E., 1982. Evolución del producto agrí́cola bruto en el País Vasco peninsular, 1537-1850. In: Goy, J., Le Roy Ladurie, E. (Eds.), Prestations paysannes, dîmes, rente foncière et mouvements de la production agricole à l'époque pré-industrielle. Mouton, París, pp. 313-327.

Engerman, S.L., Sokoloff, K.L., 2002. Factor endowments, inequality, and paths of development among new world economics. NBER Working Paper N ${ }^{\circ} 9259$.

Eiras Roel, A., 1982. Dîme et mouvement du produit agricole en Galice, 1600-1837. In: Goy, J., Le Roy Ladurie, E. (Eds.), Prestations paysannes, dîmes, rente foncière et mouvements de la production agricole à l'époque pré-industrielle. Mouton, París-La Haya, pp. 341-358. 
Fernandez de Pinedo, E., et al., 1980. Centralismo, ilustración y agonia del antiguo régimen (1715-1833). Editorial Labor, Barcelona.

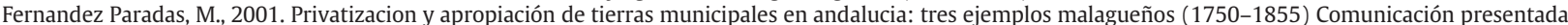
en el congreso de historia económica de Zaragoza.

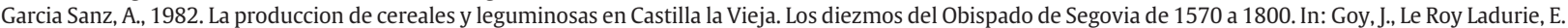
(Eds.), Prestations paysannes, dîmes, rente foncière et mouvements de la production agricole à l'époque pré-industrielle. Mouton, París.

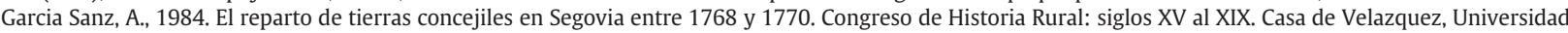
Complutense, Madrid.

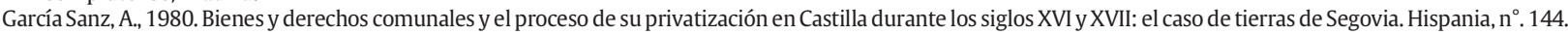
González Enciso, A., 1992. Historia económica de la España moderna. Actas, Madrid.

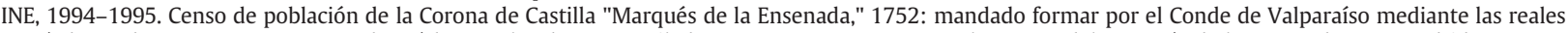
órdenes de 31.7.1756 y 9.7.1759, basańdose en los datos recopilados entre 1750 y 1754 para el catastro del Marqués de la Ensenada. INE, Madrid.

Jovellanos, G., 1744-1788. Informe sobre la ley agraria. Madrid.

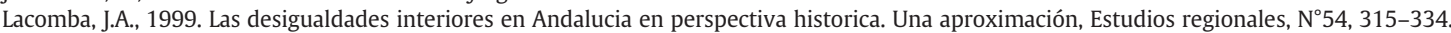

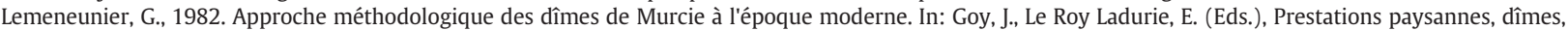
rente foncière et mouvements de la production agricole à l'époque pré-industrielle. Mouton, París, pp. 341-358.

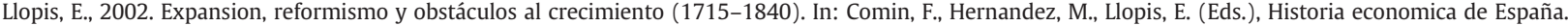
Critica, Barcelona.

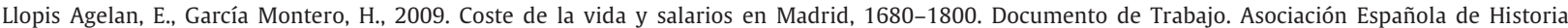
Económica. $\mathrm{N}^{\circ} 090$.

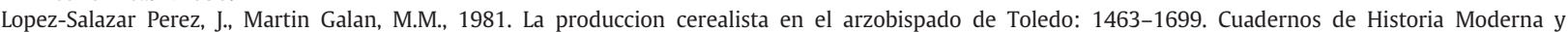
Contemporánea 21-104.

Melon Jimenez, M.A., 1987. Los diezmos de la iócesis de coria. Studia historica. Historia moderna, ISSN 0213-2079, N 5.

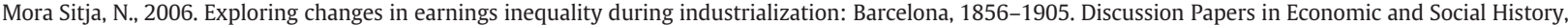
University of Oxford, N.61.

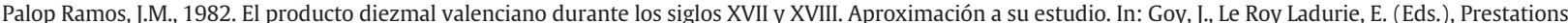
paysannes, dîmes, rente foncière et mouvements de la production agricole à l'époque pré-industrielle. Mouton, París, pp. $407-416$.

Ponsot, P., 1969. En Andalousie occidentale. Les fluctuations de la production du ble sous l'Ancien Regime. Études Rurales 34, $97-112$.

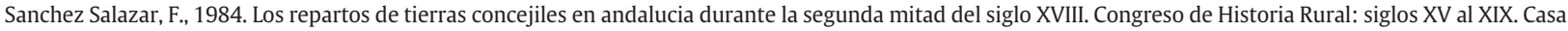
de Velazquez, Universidad Complutense, Madrid.

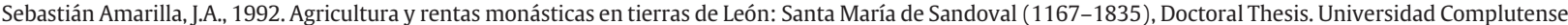
de Madrid, Madrid.

Simpson, J., 1989. La produccion agraria y el consumo español en el siglo XIX. Revista de Historia Economica Año VII (2), 355-388.

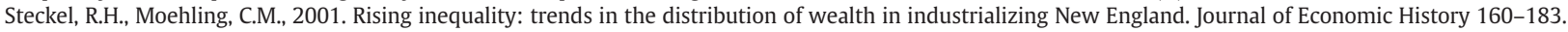

Vidal, J.J., 1978. La evolución de la producción agrícola en Mallorca durante la Edad Moderna. Fuentes y problemas de su estudio. Moneda y Crédito 67-99. 